\title{
Re-design of Portable Pedal Basins to Prevent the Spread of the Covid-19 Virus
}

\section{Re-desain Wastafel Pedal Portabel Guna Mencegah Penyebaran Virus Covid- 19}

\author{
Nuruddin Wahyu Eko Saputro ${ }^{1}$, Dede Zulrahman ${ }^{2}$, Anis Siti Nurrohkayati ${ }^{3}$ \\ \{nuruddinw7@gmail.com ${ }^{1}$, dedezulrahman@gmail.com ${ }^{2}$, asn826@gmail.com ${ }^{3}$ \}
}

Program Studi Teknik Mesin, Universitas Muhammadiyah Kalimantan Timur

\begin{abstract}
The process of spreading covid-19 is very fast and we must always be vigilant about this one outbreak. When the disease is transmitted so quickly by hand or direct contact. When crowding out we don't know where the disease came from or from who, so we have to keep our distance, wash our hands, wear a mask. Until now, the spread of the virus has increased more than in the previous year and the number of positives every day continues to increase, while various activities must continue to run so that people can remain productive and feel safe. Therefore, the purpose of implementing the re-design of the existing sink was made to re-create a portable pedal sink that was designed in the Autodesk Inventor application and updated on the cover of all sides of the sink so that it is tidier. The manufacturing process is more flexible and there are two sinks, right and left. For the sink work system, the system is stepped on so it is safer for us to use because it is without using hands. If you look at the public in general, they still use an ordinary sink so that the Mechanical Engineering Students of the Muhammadiyah University of East Kalimantan can design and design a pedal system sink or stepping system to make it easier for the prevention of Covid-19 in the city of Samarinda.
\end{abstract}

Keywords - design; design the sink; covid-19

\begin{abstract}
Abstrak. Proses menyebarnya covid-19 sangat begitu cepat dan kita harus selalu waspada pada wabah yang satu ini. Pada saat penyakit menular begitu cepat melalui tangan atau bersentuhan langsung. Pada saat berkerumunan kita tidak tahu penyakit tersebut datangnya dari mana atau dari siapa sehingga kita harus menjaga jarak, mencuci tangan, memakai masker. Sampai saat ini penyebaran virus tersebut bertambah lebih banyak dari pada tahun sebelumnya dan jumlah yang positif setiap hari terus meningkat, sementara berbagai kegiatan harus tetap berjalan agar masyarakat tetap bisa produktif dan merasa aman. Maka dari itu tujuan dari pelaksanaan re-desain wastafel yang sudah ada dibuat adalah untuk membuat ulang wastafel pedal portable yang sudah di desain di aplikasi autodesk inventor dan diperbarui dibagian penutup semua sisi wastafel sehingga lebih rapi. Proses pembuatan sehingga lebih fleksibel dan wastafel tersebut ada dua yaitu kanan dan kiri. Untuk system kerja wastafel yaitu system injak sehingga lebih aman untuk kita pakai karena tanpa menggunakan tangan. Kalau dilihat masyarakat pada umumnya masih menggunakan wastafel biasa sehingga Mahasiswa Teknik Mesin Univrsitas Muhammadiyah Kalimntan Timur untuk dapat mendesain serta merancang wastafel sistem pedal atau sistem injak supaya mempermudah untuk pencegahan covid-19 di kota samarinda.
\end{abstract}

Kata Kunci - desain; rancang wastafel; covid-19

\section{Pendahuluan}

Mencuci tangan merupakan hal sederhana, namun memiliki peranan yang sangat penting dalam kehidupan seharihari. Pemerintah melalui Kementerian Kesehatan juga telah berkomitmen untuk melaksanakan Program Sanitasi Total Berbasis Masyarakat (STBM), dimana salah satu bentuk komitmen itu adalah menyelenggarakan kegiatan sosialisasi implementasi cuci tangan pakai sabun dalam keseharian [1]. Air memegang peranan yang sangat penting dalam kehidupan manusia. Peranan tersebut dapat terlihat dari tingkat kebutuhan manusian dalam penggunaan di kegiatan sehari - harinya. Tingginya tingkat kebutuhan terhadap air tidaklah sebanding dengan ketersediaan air dibumi, karna dari air yang ada dibumi $97 \%$ adalah air laut, 3\% sisanya adalah air tawar, dan hanya $1 \%$ saja yang tersedian untuk digunakan seluruh manusia [2].

Awal tahun 2020, COVID-19 menjadi masalah kesehatan masyarakat pada umumnya. Kasus ini diawali informasi dari Badan Kesehatan Dunia /World Health Organization (WHO) tanggal 31 Desember 2019 yang menyebutkan adanya kasus kluster pneumonia dengan etiologi yang tidak jelas di Kota Wuhan, Provinsi Hubei, China. Kasus ini terus berkembang hingga adanya laporan kematian dan terjadi di China. Pada tanggal 30 Januari 2020, WHO menetapkan COVID-19 sebagai Public Health Emergency of International Concern (PHEIC). Pada tanggal 12 Februari 2020, WHO resmi menetapkan penyakit novel corona virus pada manusia ini dengan sebutan Corona virus 
Disease (COVID19). Pada tanggal 2 Maret 2020 Indonesia telah melaporkan 2 kasus konfirmasi COVID-19. Pada tanggal 11 Maret 2020, WHO sudah menetapkan COVID-19 sebagai pandemi [3].

Penyebaran covid-19 dapat dicegah dengan berbagai upaya. Kesadaran masyarakat untuk menjaga kebersihan dan kesehatan sangat perlu, beberapa upaya yang dapat dilakukan mencegah penularan covid-19, yaitu mencuci tangan dengan menggunakan sabun, menggunakan masker saat berada diluar ruangan, menjaga jarak dan menjaga daya dahan tubuh, menerapakan physical distancing dan isolasi mandiri serta membersikan rumah dan melakukan disinfeksi secara rutin. Salah satu upaya yang diterapkan kepada masyarakat yaitu meningkatkan kesadaran masyarakat untuk menjadikan mencuci tangan dengan sabun menjadi sebuah budaya baru dalam menghadapi Covid-19 [4]. Mencuci tangan adalah pangkal kebersihan dan kesehatan. Tangan adalah sumber kuman dan bakteri yang dapat menyebabkan beragam penyakit. Cuci tangan minimal 20 detik dengan menggunakan sabun, dan air mengalir, Langkah ini efektif membunuh kuman dan bakteri termasuk virus corona.

Akhir-akhir ini kita sering menjumpai adanya wastafel cuci tangan portable di berbagai tempat. Bukan lagi hanya ada di tempat makan, namun hampir semua pusat keramaian seperti toko, kantor, taman, tempat ibadah, dan lainya sebagainya ada yang berfungsi untuk menjaga kebersihan ini. Tak hanya tempat cuci tangan portable saja, namun biasanya juga sudah ada sabun (hand soap) yang bersanding di sebelahnya. Dengan adanya wastafel portable ini maka dapat menjadi indikasi bahwa kesadaran akan menjaga kebersihan badan khususnya tangan sudah dipahami hampir semua kepentingan. Masyarakat pun tanpa berat hati juga telah memanfaatkan wastafel cuci tangan tersebut untuk menjaga kebersihan baik sebelum atau sesudah mendatangi suatu tempat umum. Alhasil upaya menjaga tangan tetap higienis telah berjalan sebagaimana telah diharapkan. Jika dilihat-lihat dari sebuah wastafel cuci tangan yang ada hanya berupa penyediaan sumber air dan sabun tanpa adanya tempat untuk bak untuk menampung air. Ada yang hanya berupa ember sebagai wadah, ada yang menggunakan ember atau galon tanpa wadah, ada pula yang menggunakan wastafel cuci piring namun difungsikan sebagai fasilitas cuci tangan. Jika hanya bersifat sementara tentu ini gak jadi masalah, akan tetapi jika sudah beberapa minggu berjalan namun masih dengan wastafel ala kadarnya sepertinya kurang representatif. Selain tidak bisa digunakan secara maksimal bentuk yang ala kadarnya juga merusak keindahan suatu halaman. Apalagi untuk kantor instansi atau toko yang sudah bagus, seperti sudah tak layak jika asal menggunakan wastafel ala kadarnya.

Pada awal kemajuan perkembangan rancangan, gambar sudah dituangkan ke dalam kertas. Kemudian hasil dari gambar dibuat model rancangan pendahuluan dengan bentuk yang sesuai tetapi dengan bahan yang berbeda. Sebagai contoh pembuatan wastafel portabel pedal, ketika gambar rancangan telah selesai, lalu dibuatlah prototype wastafel portabel pedal sesuai dengan ukurannya. Bahasa gambar sekarang menjadi metode membuat gambar yang relative tepat, maka pembuatan model kerja sebagai pendahuluan untuk konstruksi hampir sudah tidak diperlukan lagi. Dikarenakan kini sudah banyak perangkat lunak CAD (Computer Aided Desain) [5].

Berdasarkan uraian tersebut, tujuan dari pelaksanaan rancang bangun ini yaitu membuat alat cuci tangan atau wastafel portable pedal yang dimana tanpa harus menyentuh dengan tangan tetapi dengan menggunakan pedal atau system injak yang sudah di desain di aplikasi autodesk inventor yang sudah dilakukan mahasiswa S1 Teknik Mesin Universitas Muhammadiyah Kalimantan Timur.

\section{METODE}

Perancangan atau desain wastafel portabel ini bertujuan untuk melakukan perencanaan desain ulang dibagian penutup semua sisi sehingga lebih rapi. Pembuatan wastafel portabel yang mudah digunakan dan berbeda dari wastafel yang sudah ada. Wastafel portabel ini diharapkan bisa mempermudah masyarakat untuk mencuci tangan secara higienis. Serta diharapkan untuk pencegahan covid-19. Wastafel pedal portable ini diharapkan bias mengubah masyarakat menjadi lebih rajin mencuci tangan. Pengembangan desain frame yang telah dilakukan penelitian sebelumnya menunjukan bahwa frame memiliki kekurangan yaitu kaki kurang tegak diakibatkan karena kurang ketelitian pada saat pemotongan sudut kaki-kaki frame. Pada saat perakitan kaki-kaki frame juga sedikit mengalami pelengkungan akibat arus las. Adanya cacat las pada frame. Cacat las diakibatkan karena penggunaan arus yang tidak sesuai dengan benda kerja yang dipakai. Ukuran tidak sesuai dengan gambar kerja. Ukuran-ukuran tersebut berbeda akibat pemuaian dan pelengkungan pada saat perakitan bahan menggunakan las listrik [6]. Metodologi perancangan pembuatan wastafel portable dengan sistem injak diberikan pada gambar berikut : 


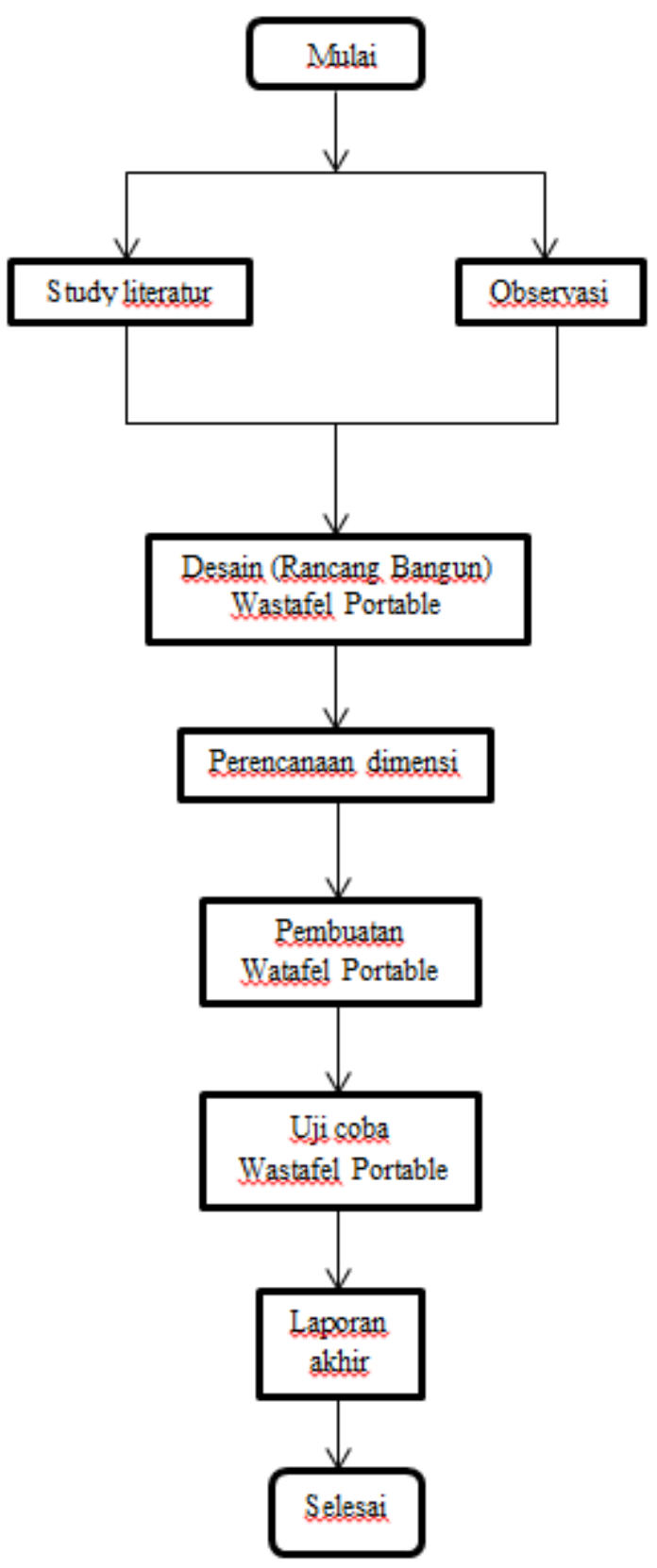

Gambar 1. Proses pembuatan wastafel portable

Pada dasarnya wastafel portabel ini bekerja dengan cara system injak pedal. Pedal sebelah kanan untuk sabun dan pedal sebelah kiri untuk keluarnya air dari pipa saluran air yang sudah dirancang sebelumnya. Untuk bak wastafel memakai yang sudah ada dijual dipasaran dan untuk rangka memakai besi siku 4 x 4, besi as untuk sambungan pedal ke sabun serta pedal ke keran. 


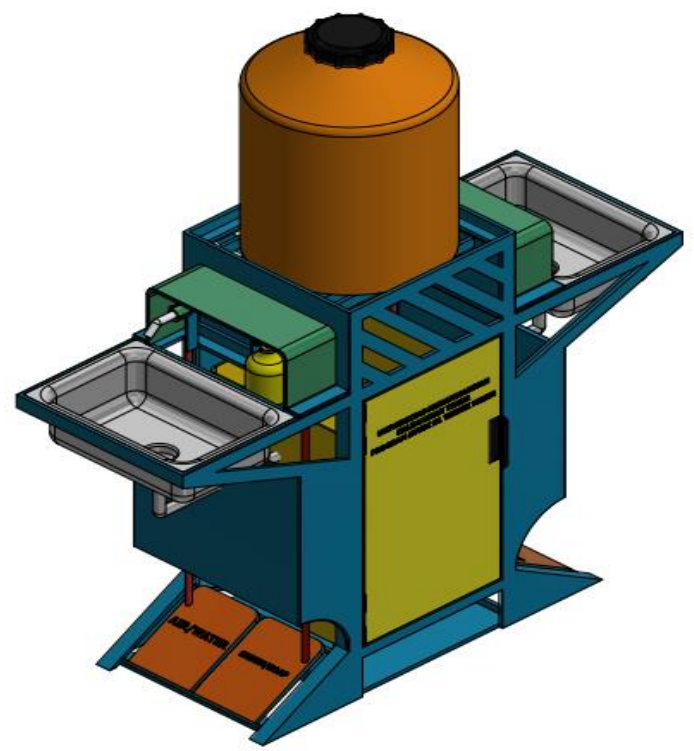

Gambar 2. Desain Wastafel Pedal Portabel

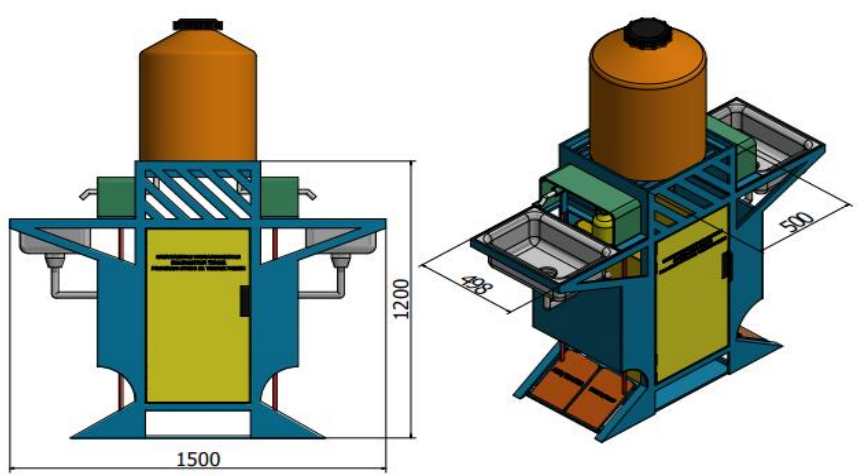

Gambar 3. Desain wastafel pedal portable dan ukurannya

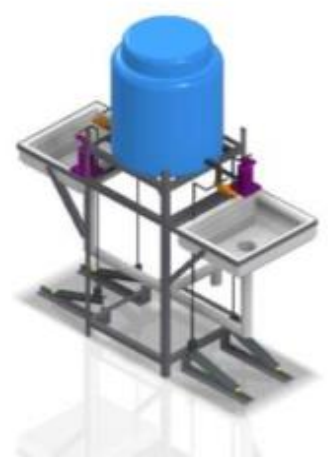

Gambar 4. Desain Wastafel portable sebelumnya 


\section{Hasil dan Pembahasan}

Pada desain wastafel portabel ini, perancang telah merancang yang lebih sederhana, menggunakan aplikasi autodesk inventor dengan kemampuan mendesain tiga dimensi untuk pembuatan objek yang diinginkan desainer yaitu objek 3D secara visual. Software ini menyediakan secara lengkap fasilitas yang menunjang dalam pembuatan model 3D penggabungan atau system merakit (Assemblay), gambar yang bisa diterapkan (Drawing), animasi, simulasi dan drafting beserta dokumentasi data-datanya. Dalam inventor, seorang desainer bisa membuat sketsa 2D, dan menjadikan menjadi 3D selanjutnya bisa di simulasi [7].

\section{A. Rancangan wastafel portable}

Prinsip kerja dari wastafel portable yaitu dengan system menginjak pedal terlebih dahulu supaya air dan sabun bisa keluar secara otomatis dan menjadikan proses mencuci tangan sangat higienis tanpa perlu menyentuh kran. Adapun tahapan pembuatan wastafel portable dilakukan di Laboratorium Teknik Mesin Universitas Muhammadiyah Kalimantan Timur adalah sebagai berikut :

\section{Pembuatan rangka}

Dalam perencanaan rangka pada wastafel ini tidak dilakukan perhitungan kekuatan struktur, hanya memilih bahan kerangaka yang diperkirakan mampu menahan beban secara keseluruhan yang tidak terlalu berat. Rangka pada wastafel menggunakan besi $\mathrm{L}$ atau bisa dinamakan besi siku yang sudah banyak dijual dikalanagan umum. Saat proses penyambungan besi dengan menggunakan metode las dan wastafel ini bersifat tertutup. Jadi, semua sisi diberi pelat yang sesuai untuk menutup bagian yang terbuka sehingga hanya kelihatan system pedalnya saja kalau dilihat dari sisi luar. Untuk as poros untuk menyambung pedal tidak kelihatan. Setelah rancangan wastafel portabel pedal dibuat, kemudian dilanjutkan dengan proses merakit atau merangkai yang dilakukan di Laboratorium Teknik Mesin. Proses pembuatan wastafel ini relatif cepat karena tidak ada bagian yang sulit dikerjakan dan hal ini menjadi pertimbangan di awal ketika melakukan proses desain dan perancangan.

\section{Pembuatan system pedal}

Pada tahap ini kami mulai merakit pedal, yakni proses penyambungan plat ringan yang telah dipotong dengan menggunakan metode las sebagai penyambung plat dan menggunakan sistem baut dan mur serta besi as untuk poros yang akan di hubungkan ke kran air.

Uji coba pedal wastafel

Pengujian pedal dilakukan 2 kali yaitu pada pedal kanan dan kiri yaitu ada 4 buah pedal untuk mengetahui kekuatan pedal dan apakah air dan sabun sudah berfungsi dengan maksimal.

Pengecatan wastafel

Pada tahap ini dilakukan pengecatan Permukaan yang akan dicat harus bebas dari debu, kotoran, minyak, karat, lembab, dll.

\section{Pemasangan plat nama atau institusi}

Proses pemasangan plat yang bertuliskan prodi S1 Teknik Mesin UMKT dengan cara cat semprot. Sebelumnya dibuat terlebih dahulu mal nya selanjutnya ditempel dan melakukan penyemprotan cat atau pilok dan sebanyak 1 unit plat yang diberi nama institusi.

\section{B. Pengujian wastafel portable pedal}

Pengujian wastafel portable pedal dilakukan untuk mengetahui apakah hasil rancangan dan rangkaian ini dapat difungsikan sesuai harapan atau tidak. Kalau masih ada yang tidak sesuai maka dilakukan perbaikan pada bagian yang belum sesuai dengan harapan. Hasil pengujian dilakukan dengan menginjak pedal dengan kaki disetiap pedal yang ada yaitu ada empat pedal yang telah dibuat. Pada pengujian wastafel portable pedal dilakukan 2 pengujian yaitu :

\section{Pengujian system pedal}

Pengujian pedal dilakukan untuk melihat apakah pedal sudah berjalan sesuai dengan yang diinginkan atau belum. Dalam proses pengujian ini, tahap pertama yang diuji adalah melihat pengaruh sistem pedal terhadap kran air. Berdasarkan pengujian pada sistem pedal dimana pedal yg di injak akan menggerakan per tekan kemudian kran akan otomatis berputar.

\section{Pengujian alat secara keseluruhan}

Pengujian dilakukan untuk melihat apakah alat secara keseluruhan sudah berjalan sesuai dengan yang diinginkan atau belum. Berdasarkan pengujian yang dilakukan pada setiap pedal yang ada pada sistem wastafel ini, alat sudah mampu bekerja sesuai dengan yang diinginkan. Hal ini terbukti saat pedal kiri dan kanan di injak maka kran air akan terbuka dan mengeluarkan air dan sabun. 


\section{KESIMPULAN}

Pelaksanaan pembuatan wastafel portable pedal sebagai upaya pencegahan covid-19 ini telah diselesaikan sesuai dengan rencana, mulai dari membuat desain, merancang dan sampai jadi produk wastafel portable yang dibuat dengan system pedal yang ditekan dengan kaki untuk mengeluarkan air dan sabun, sehingga tidak ada yang menggunakan tangan untuk proses mencuci tangan menggunakan wastafel portable pedal.

\section{UCAPAN TERIMAKASIH}

Ucapan terimakasih disampaikan kepada dosen dan mahasiswa yang telah berperan dalam penelitian re-desain wastafel pedal portable pada guna pencegahan virus covid-19 khususnya di Kota Samarinda Kalimantan Timur. Dan berterimakasih kepada pihak Laboratorium S1 Teknik Mesin Universitas Muhammadiyah Kalimantan Timur yang telah memberi izin untuk penelitian tersebut.

\section{REFERENSI}

[1] W. Hafikur Riski, "Rancang Bangun Sistem Wastafel Otomatis Berbasis Mikrokontroler Atmega8535 Dengan Menggunakan Sensor Fotodioda”, Jurnal Fisika Unand, p.106, 2015.

[2] A. S. A. B. Rezky, "Rancang Bangun Kran Wastafel Otomatis Berbasis Arduino Nano dan Sensor Ultrasonik HC-SR04 pada Kampus Politeknik Amamapare Timika," Teknik AMATA, pp. 20-23, 2020. aplikasi bisnis.Andi, Yogyakarta.

[3] S. N. Luthfi Parinduri, "Evaluasi Pembuatan Wastafel Portable Anticovid-19," Semnastek Uisu, P. 65, 2020.

[4] N. W. E. S. A. S. N. Muhammad Khairul, "PKM Penyerahan Wastafel Portabel Pedal Sebagai Upaya Pencegahan Covid-19 di Kelurahan Bantuas Kecamatan Palaran Samarinda," Seminar Nasional Unimus, pp. 2-3, 2020.

[5] D. Seprianto, "Perancangan Alat Blending/Mixing Menggunakan Perangkat Lunak Cad Autodesk Inventor Professional 2010," Jurnal Austenit, p. 52, 2011.

[6] M. K. T. H. Desendra Aufana, "Perancangan Dan Simulasi Tegangan Frame Mesin Pengisian Curah Tembakau," Jurnal CRANKSHAFT, p. 10, 2019.

[7] M. A. H. Bambang Setyono, "Perancangan Dan Analisis Kekuatan Frame Sepeda Hibrid "Trisona" Menggunakan Software Autodesk Inventor," Jurnal IPTEK, p. 38, 2016.

[8] M. K. Sari, "Sosialisasi Tentang Pencegahan Covid-19 Di Kalangan Siswa Sekolah Dasar Di SD Minggiran 2 Kecamatan Papar Kabupaten Kediri," Karya Abdi, pp. 80-83, 2020. 